\title{
Analysis of Creative Skills in Various Secondary School Programs in Slovenia
}

\author{
Jerneja Herzog \\ University of Maribor, Faculty of Education
}

\section{Abstract}

There is a lack of research in the field of monitoring artistic creativity in secondary schools in Slovenia, so a study was conducted on the population of 81 pupils of different secondary school programs in Slovenia, aged 16 years, where we monitored artistic creative abilities. We analysed the achievements of pupils in terms of common artistic abilities, and examined differences between groups of factors of artistic creativity which encourage and enable artistic creativity, as well as in terms of differences in individual factors of artistic creativity. The analysis was aimed at identifying the differences between different secondary school programs.

The results show that pupils in the art secondary school program generally lead the way. However, the pupils of the general secondary school program achieved better results in the factor of artistic originality. Such a result confirms that good results can be achieved in the field of development of artistic creativity also in general secondary school programs with the appropriate art pedagogical work.

Key words: artistic creativity; creativity; factors of artistic creativity; pupils

\section{Introduction}

In spite of the knowledge about the importance of creative thinking and the fact that it is based on the overall social progress, too little attention is paid to this segment (Kemple \& Nissemberger, 2000). The authors add that the school system is to blame. Teachers should pay more attention to developing creativity and critical thinking. Runco (2007) says that we should pay attention to all forms of creativity, especially when talking about the educational system. Among other things, this is due children having a constant desire to work and create new things, says Runco (2007), and they do not care about the end result, especially in singing, drawing, playing and perceiving 
their own environment. It follows that creativity in children and adolescents can be developed. However, it is interesting that creativity, unlike intelligence, does not decline with age. For example, Titian painted some of his best paintings at age 98, Goethe created Faust at age 80, and Edison patented inventions at 84 (Pecs, 2004). Even because of the awareness that creative abilities can be developed, creativity is still a topical subject of research. In the recent period, it has increasingly shown itself to be an extremely important factor in the overall development of the individual and as such represents a topical issue in contemporary research.

Much is known about general creativity, and there are many definitions for which Trstenjak (1981) thinks that they are not uniform in their content. Creativity research has long considered creativity as a unitary construct, defining it as a general ability to produce work that is both novel and appropriate (Mumford, 2003; Plucker et al., 2004; Runco, 2007). Research that limits itself to three types of creativity based on self-ratings is also interesting (Kaufman \& Baer, 2004; Oral et al., 2007). These three types are:

- artistic / Bodily ('hands-on' creativity in art, craft, and bodily / physical creativity),

- math / science (creativity in math and science)

- and Writing / Communication (creativity and interpersonal relationships, communication, and writing) (ibid.).

It is interesting to note that researchers Ward et al. (1999) concluded that achievement in one area of creative endeavour (such as painting or scientific discovery) does not necessarily imply creative excellence in all areas. Researchers Kozhevnikvov et al. (2013) have shown in the research that "the results showed that object visualization (ability and style) related to artistic creativity, and spatial visualization (ability and style) related to scientific creativity, and both are distinct from verbal creativity. The three factors revealed in the factor analysis (object / artistic, spatial / scientific, and verbal / literature) are consistent with the three main modes of information processing (visual - object, visual - spatial and verbal" (ibid., p. 204).

In our paper we will limit ourselves to visual art creativity, where we will come from artistic creativity. In order to understand the intrinsic value of the artistic experience, it is important to realize that the artwork is a kind of bridge between the mind of the artist and the viewer of the artwork (Herzog, 2008). Duh believes that "Visual art creativity can be defined in exactly the same way as artistic, assuming that we add specific artistic elements to it, that is, visual artistic and expressive means. The artwork is a product of the creative process and is multi-layered and multi-faceted. Multifacetedness is reflected in the complexity of the creation of a work of art" (Duh, 2004, p. 22), in the design of fine arts, the creative environment and the creative process. The creative process is underpinned by absorption, inclination for imagination and daydreaming, according to Peres Fabello and Campos (2011)."The imagination, absorption and the imaginary process together enable unlimited exploration of habits or facts. Through dreams and imagination, intuition, creativity and other unconscious processes can develop" (ibid., p. 38). 
Since we are most interested in the achievements of art, that is, the product, in this article, we will separately highlight the factors of visual art creativity. When talking about the factors of visual art creativity, we should mention a model of creativity, which, according to the product of Guilford $(1967,1968)$, is divided into two groups of three factors. The first group includes factors that enable creativity and the second, those that encourage it. The group that enables artistic creativity includes artistic redefinition, artistic fluency and artistic elaboration. The group that encourages artistic creativity, however, consists of artistic originality, flexibility and sensitivity to artistic problems.

Looking more closely at the factors that enable artistic creativity, we can say that artistic redefinition manifests itself "as a conscious redefinition of an idea, material or visual impression into something new" (Herzog, 2009, p. 21). It represents the ability to "dismantle existing ones and re-experimentally or purposefully combine them (pupils try to sketch multiple options to arrange a visual inventory (desk, person, dog, etc.)" (Dinkelmann, 2008, p. 19). Vrlič (2001, p. 46) says that artistic fluency "shows in a wealth of ideas, moves, hypotheses, associations". Herzog (2009) adds that fluency shows "in motor skills that allow for various fine operations and richer visual arts" (ibid., p. 22). "It means the ability to easily retrieve known information. How is this reflected in fine arts class? Pupils e.g. in the use of blue quickly name a number of blue natural phenomena and objects" (Dinkelmann, 2008, p. 19). For artistic elaboration, Vrlič (2001) says that it means the ability to develop new imaginations and plan ahead. With this factor, "we monitor the planning of the aesthetic expression, it is shown as the conformity of the idea and the visual material with respect for the artistic and design principles" (Herzog, 2009, p. 22).

Next, we will look at the factors that encourage creativity. According to Vrlič (2001), in the creation of art, originality is manifested by unexpected artistic solutions, combining unusual and imaginative ideas. "It means the ability to generate new ideas, the rarer the ideas, the more original they are" (Dinkelmann, 2008, p. 19). Artistic flexibility is the ability to solve tasks in a variety of ways and discover new ideas. This factor "monitors the adaptation to expressive means, but is shown as a coherence of the artistic idea with the artistic materials used," according to Herzog (2009, p. 22). Means "the ability to dissect and experiment with existing things or to re-assemble them (The pupil comes up with the idea of understanding the word "blue" in the figurative sense: "make blue", "I am feeling blue", "the blues") (Dinkelmann, 2008, p. 19). Qualitative factors include sensitivity to visual problems. This is a factor in which we immediately perceive what matters. In artistic engagement, this is a sensory perception of colours, shapes, artistic connection, harmony and balance (Vrlič, 2001). It "monitors the experience and interpretation of a visual problem that manifests itself in the sensibility of a visual solution" (Herzog, 2009, p. 22). It means "the ability to recognize the need for change and the gaps (the learner sees that the visual product and the slogan of his visual product are not visible enough because the colours are too bright, so he decides and enhances the colours and creates contrast)" (Dinkelmann, 
2008, p. 19). Duh (2004) believes that the factors of creativity complement each other and form a whole together. Herzog $(2009$, p. 30) agrees, adding that "by developing any factor of creativity, we indirectly develop and encourage all others." However, raising the whole of the creativity in the classroom can be achieved by "alternately activating the various factors of artistic creativity that it activates in pupils" (ibid.).

\section{Research Problem}

If we confine ourselves to the results of research in elementary school, we can say that there is a positive effect on visual development, as well as creativity, knowledge and appreciative abilities, when teachers use different didactic approaches (Herzog \&Duh; 2015; Herzog, 2017; Herzog et al., 2017). Even in the field of secondary education, the monitoring of visual skills (Kač Nemanič, 2017; Duh \& Kač Nemanič, 2018; Kač Nemanič, 2019) shows a positive effect of introducing an innovative approach and minor didactic changes. Taking into account three different secondary school programs (creative arts secondary school program, general secondary school program and classical secondary school program) and consequently three different content and didactic approaches, in our research we were interested in the level of artistic creative abilities of the pupils of all three mentioned secondary school programs. Thus, the factors of artistic creativity that we have presented in detail are the basis for the development of our research, the results of which will be presented below.

\section{Methods}

\section{Purpose and Objectives of the Research}

The purpose of the research was to examine the artistic abilities of the first year pupils (16 years) of different secondary school programs. We were interested in the differences in the achievements of the pupils of the creative arts secondary school program, the general secondary school program and the classical secondary school program.

Table 1

Percentage of hours of art lessons in the 1st year by type of secondary school program

\begin{tabular}{|c|c|c|c|}
\hline $\begin{array}{l}\text { A type of secondary } \\
\text { school program }\end{array}$ & SUBJECT & $\begin{array}{l}\text { No. of } \\
\text { Hours }\end{array}$ & Notes \\
\hline \multirow{3}{*}{ Art secondary school } & Art theory & 70 & \\
\hline & Presentation techniques & 70 & \\
\hline & Drawing and painting & 105 & \\
\hline $\begin{array}{l}\text { General } \\
\text { school }\end{array}$ & Fine arts & 70 & $\begin{array}{l}35 \text { hours Artistic design } \\
35 \text { hours Art History }\end{array}$ \\
\hline $\begin{array}{l}\text { Classical } \\
\text { school }\end{array}$ & Fine arts & 70 & $\begin{array}{l}35 \text { hours Artistic design } \\
35 \text { hours Art History }\end{array}$ \\
\hline
\end{tabular}

Given the predisposition that the creative arts secondary school program contains a personalized program for high-performing pupils, we were interested in whether the higher scores on individual factors of artistic creativity are shown exclusively in the pupils of the aforementioned program. It is well known that creative arts secondary 
school programs carry out augmented content in the field of fine arts, as shown by the presented subject in Table 1. While general secondary school programs provide fine arts content (70 hours) in the first year only. To this extent, the proportion (35 hours) is devoted to the practice of art, i.e. art design and a share (35 hours) devoted to art history.

\section{Research Hypotheses and Research Questions}

In awareness that pupils (Table 1) have more content available in the course that influence the development of creative skills, we formulated three research hypotheses:

$H_{1}$ : We envisage the existence of statistically significant differences in the total level of creative ability in favour of pupils of creative arts secondary school.

$\mathrm{H}_{2}$ : We envisage the existence of statistically significant differences in the common level of factors that enable visual arts creativity (the interaction of the factors fluency, redefinition, and elaboration) in favour of pupils of creative arts secondary school.

$\mathrm{H}_{3}$ : We envisage the existence of statistically significant differences in the common level of factors that stimulate artistic creativity (the interaction of the factors flexibility, originality, and sensitivity to art problems) in favour of pupils of creative arts secondary school.

Content related to fine arts in general and classical secondary school curriculum provides teachers with a variety of didactic approaches that can be reflected in specific fields. To this end, we formulated 6 research questions that relate exclusively to the analysis of individual factors of visual arts creativity.

$R V_{1}$ : Which pupils achieved better results in artistic elaboration?

$R V_{2}$ : Which pupils achieved better results in artistic redefinition?

$R V_{3}:$ Which pupils achieved better results in artistic flexibility?

$R V_{4}$ : Which pupils achieved better results in artistic originality?

$R V_{5}:$ Which pupils achieved better results in artistic sensitivity to artistic problems?

$R V_{6}:$ Which pupils achieved better results in visual fluency?

Research Method

In the research we used quantitative methodology of scientific pedagogical research with causal non-experimental method in pedagogical empirical research.

\section{Research Sample}

A total of 81 first year pupils were included in the research sample, with a more detailed breakdown by type of secondary school program shown in Table 2.

Table 2

Percentage of pupils by type of curriculum

\begin{tabular}{llcc}
\hline \multirow{2}{*}{ Secondary school } & Secondary school curriculum & \multicolumn{2}{c}{ Number of pupils } \\
& & $\mathrm{F}$ & $\mathrm{f} \%$ \\
\hline Gimnazija Celje - Center & Creative arts secondary school & 30 & 37.00 \\
Prva gimnazija Maribor & General secondary school & 27 & 33.00 \\
Škofijska gimnazija Antona & Classical secondary school program & 24 & 30.00 \\
Martina Slomška Maribor & & 81 & 100 \\
Total & & & \\
\hline
\end{tabular}




\section{Data Collection Process}

Data collection took place during the 2018-19 school year. The pupils were tested to the extent of 60 minutes after a pre-arranged date and with the consent of the school management and parents.

\section{Instrumentation Description}

We used part of the LK-AP test to test creativity and visual expression. The whole test involves checking the creative skills, artistic perceptual abilities, and artistic receptive abilities. In our research, we have limited ourselves to fine arts. The LK-AP test, which has already been used in whole or in part in many other studies (Karlavaris \& Kraguljac, 1970; Berce-Golob, 1990; Duh 2004; Duh, Čagran, \& Huzjak, 2012; Duh, Zupančič \& Čagran, 2014; Kač Nemanič, 2018) has produced reliable results. The LK-AP test (Karlavaris, 1970) consists of two parts, the LK test, which covers a questionnaire for artistic creativity for measuring artistic and creative abilities, and the AP test, which covers a questionnaire for measuring artistic and appreciative abilities and knowledge. The factors of artistic creativity were monitored by the aforementioned test, with tasks that included refining and scaling point solutions. The LK-AP test is similar to the LV1 test, slightly modified in one task. However, it consists of two parts, where the sequence of tasks is arranged in such a way that it follows in types. The first part of the questionnaire (questions 6-11) monitors the pupils' artistic and creative development and the tasks are designed in such a way that the test subjects draw or independently draw a specific character that meets the set requirements (Duh, 2004). We used this part in our research. A maximum of 66 points could be scored on the test, of which 36 points in the tasks that accompanied the creativity factors that stimulate the creativity and 30 points in the tasks that accompanied the creativity factors that enabled the creativity.

\section{Data Processing Procedure}

Data were processed with the SPSS computer program, which is intended for statistical data processing. We obtained results showing an arithmetic mean (x), standard deviation (s), variance homogeneity test and arithmetic mean difference test. We used the Kruskal-Wallis test to determine differences between pupils in different secondary school programs.

Table 3

Basic descriptive statistics of total values of visual creativity by total sample

\begin{tabular}{lcccccc}
\hline Artistic creativity & MIN & MAX & $\begin{array}{c}\text { Arithmetic } \\
\text { mean }\end{array}$ & $\begin{array}{c}\text { Standard } \\
\text { deviation } \\
\text { s }\end{array}$ & KA & KS \\
\hline Total & 14.00 & 41.00 & 25.8642 & 5.87953 & 0.146 & 0.529 \\
\hline
\end{tabular}

Skewness is asymmetric to the right $(\mathrm{KA}>0)$ at the total level of artistic creativity, which indicates the dominance of small values. The kurtosis indicates a pointed distribution $(K S>0)$, which indicates that the results in the overall level of artistic creativity are very similar to each other and quite high or extremely high. 
In the following, we examined the existence of differences in the overall level of artistic creativity from the perspective of the secondary school curriculum.

Table 4

Results of the Kruskal-Wallis test on the total value of visual creativity by total sample

\begin{tabular}{llcccc}
\hline Artistic creativity & \multicolumn{1}{c}{ Secondary school curriculum } & $\mathrm{n}$ & $\bar{R}$ & $\chi^{2}$ & $\mathrm{p}$ \\
\hline \multirow{3}{*}{ TOTAL } & Creative arts secondary school program & 30 & 54.65 & & \\
& General secondary school program & 27 & 35.00 & 16.538 & 0.000 \\
& Classical secondary school program & 24 & 30.69 & & \\
\hline
\end{tabular}

The result of the Kruskal-Wallis test indicates that there are statistically significant differences in the overall level of artistic creativity $\left(\chi^{2}=16.538, \mathrm{P}=0.000\right)$, which is in favour of the pupils of the creative arts secondary school program. As we had already assumed in designing the research hypothesis, we expected such a result, because not only did the pupils of the creative arts secondary school program have more content related to the fine arts, but they also had a greater affinity and, after all, they passed the entrance exam for enrolment in the creative arts secondary school program. The obtained result thus confirms the research hypothesis $\mathrm{H}_{1}$, with which we predicted the existence of statistically significant differences in favour of the pupils of the creative arts secondary school program in the total value of artistic creative abilities.

In the following, we were interested in whether there was a difference in the achievement of pupils from different secondary school programs in terms of the common level of factors that enable artistic creativity.

Table 5

Basic descriptive statistics of the total values of the factors that enable creativity

\begin{tabular}{lcccccc}
\hline $\begin{array}{l}\text { Factors of creative creativity } \\
\text { that enable creativity }\end{array}$ & MIN & MAX & $\begin{array}{c}\text { Arithmetic } \\
\text { mean }\end{array}$ & $\begin{array}{c}\text { Standard } \\
\text { deviation } \\
\text { s }\end{array}$ & KA & KS \\
\hline Total & 4.00 & 25.00 & 12,8765 & 4.29355 & 0.274 & 0.529 \\
\hline
\end{tabular}

Skewness is in the group of factors that allow artistic creativity to be asymmetric to the right $(\mathrm{KA}>0)$, which indicates the predominance of small values. The kurtosis indicates a flattened distribution $(\mathrm{KS}<0)$, which indicates that the results in the group of factors that stimulate creativity are very similar between and indicate small variations in distribution.

Table 6

Results of the Kruskal-Wallis test on the total value of factors that allow for creativity

\begin{tabular}{lllllll}
\hline $\begin{array}{l}\text { Factors of creative creativity } \\
\text { that enable creativity }\end{array}$ & Secondary school curriculum & $\mathrm{n}$ & $\bar{R}$ & $\chi^{2}$ & $\mathrm{p}$ \\
\hline \multirow{3}{*}{ TOTAL } & Creative arts secondary school & 30 & 52.15 & & \\
& program & 27 & 37.13 & 11.544 & 0.003 \\
& General Secondary School & 24 & 31.42 & & \\
\hline
\end{tabular}


The results of the Kruskal-Wallis test indicate the existence of a statistically significant difference $\left(\chi^{2}=11.544, \mathrm{P}=0.003\right)$ in favour of pupils in the creative arts secondary school program. As a result of the presence of a larger set of artistic tasks or art practice. The results obtained confirm the research hypothesis $\mathrm{H}_{2}$ by which we predicted the existence of statistically significant differences in favour of pupils of creative arts secondary schools in the common level of factors that enable artistic creativity.

Below we present an analysis of the common values of the factors that stimulate creativity. First, we will present a descriptive analysis of achievements (Table 7).

Table 7

Basic descriptive statistics of the total values of the factors that enable creativity

\begin{tabular}{lcccccc}
\hline Incentives of Fine Arts & MIN & MAX & $\begin{array}{c}\text { Arithmetic mean } \\
\bar{x}\end{array}$ & $\begin{array}{c}\text { Standard } \\
\text { deviation } \\
\text { s }\end{array}$ & KA & KS \\
\hline Total & 6.00 & 17.00 & 12.1481 & 2.52543 & -0.290 & -0.166 \\
\hline
\end{tabular}

Skewness is the group of factors that stimulate creativity asymmetric to the left $(\mathrm{KA}<0)$, which indicates the dominance of higher values. The kurtosis indicates a flattened distribution $(\mathrm{KS}<0)$, which indicates that the results in the group of factors that stimulate creativity are very similar between and indicate small variations in distribution.

We further checked the existence of differences in terms of the secondary school program in the total value of the factors that stimulate artistic creativity.

Table 8

Results of the Kruskal-Wallis test on the total value of factors that allow for creativity

\begin{tabular}{llcccc}
\hline Incentives of Fine Arts & Secondary school curriculum & $\mathrm{n}$ & $\bar{R}$ & $\chi^{2}$ & $\mathrm{P}$ \\
\hline \multirow{5}{*}{ TOTAL } & $\begin{array}{l}\text { Creative arts secondary school } \\
\text { program }\end{array}$ & 30 & 56.08 & & \\
$\begin{array}{l}\text { General secondary school } \\
\text { program } \\
\text { Classical secondary school } \\
\text { program }\end{array}$ & 27 & 30.98 & & & \\
& & 24 & 33.42 & 20.106 & 0.000 \\
\hline
\end{tabular}

The result of the Kruskal-Wallis test indicates that there are statistically significant differences in the group of factors that stimulate artistic creativity $\left(\chi^{2}=20.106, P=\right.$ 0.000 ), which is in favour of the pupils of the creative arts secondary school program. The result obtained from the common level of artistic creativity can be interpreted in a similar way to that interpreted by the common values of the factors that enable artistic creativity (Table 6). The content of the creative arts secondary school program is aimed at stimulating creativity, finding new approaches and solutions, and in view of this, such an outcome is expected. This is the result by which we confirm the research hypothesis $\mathrm{H}_{3}$ by which we predicted the existence of statistically significant differences in the common level of factors that encourage artistic creativity. 
However, in the first year of secondary school programs (general secondary school program and classical secondary school program), the contents of fine arts, however, despite the relatively small amount of hours, allow for different didactic approaches and diverse artistic tasks. Thus, we were interested in a more detailed role of each factor of artistic creativity in terms of the achievements of pupils of all three secondary schools.

First, we analysed the basic descriptive statistics for each factor of artistic creativity. The results obtained are presented in Table 9 .

Table 9

Basic descriptive statistics of the results by individual factor artistic creativity

\begin{tabular}{lcccccc}
\hline $\begin{array}{l}\text { Incentives of } \\
\text { Fine Arts }\end{array}$ & MIN & MAX & $\begin{array}{c}\text { Arithmetic } \\
\text { mean } \\
\bar{x}\end{array}$ & $\begin{array}{c}\text { Standard } \\
\text { deviation } \\
\text { s }\end{array}$ & KA & KS \\
\hline Elaboration & 0.00 & 10.00 & 4.8148 & 2.26997 & -0.087 & -0.914 \\
Redefinition & 0.00 & 10.00 & 3.4691 & 2.53025 & 0.588 & -0.148 \\
Flexibility & 1.00 & 8.00 & 6.3580 & 1.19696 & -2.704 & 9.025 \\
Originality & 0.00 & 9.00 & 3.5062 & 1.87165 & 0.717 & 0.360 \\
sensitivity to art & 0.00 & 9.00 & 3.5062 & 1.87165 & 0.717 & 0.360 \\
problems & & & & & & \\
Fluency & 2.00 & 6.00 & 4.5926 & 1.21221 & -0.416 & -0.861 \\
\hline
\end{tabular}

In three cases (elaboration, flexibility and fluidity), the skewness is asymmetric to the left $(\mathrm{KA}<0)$, i.e. in the direction of higher values. In three cases (redefinition, originality, sensitivity to art problems), skewness is asymmetric to the right (KA $>0)$, which indicates lower values for these factors.

In three cases (elaboration, redefinition, fluency), the kurtosis also shows that the distribution is flattened $(\mathrm{KS}<0)$, which means that the results were differently dispersed but lower values prevailed. Other factors (flexibility, originality, sensitivity to visual problems) were dominated by a conical distribution (KS $>0$ ), which showed that the results were very similar and quite high for these factors.

The following (Table 10) presents an analysis of the differences in terms of the secondary school curriculum for each factor of artistic creativity. In doing so, we sought answers to research questions.

The table (Table 10) shows that the factor of artistic elaboration cannot detect statistically significant differences between the achievements of pupils of different secondary school programs. However, if we take a closer look at the values of the ranks, we can say that very similar results were obtained by the pupils of the creative arts and general secondary school program. With the result obtained, we answered the research question RQ1, where we were interested in which pupils would achieve better results in the factor of artistic elaboration. 
Table 10

Results of the Kruskal-Wallis test for each factor of visual creativity

\begin{tabular}{|c|c|c|c|c|c|}
\hline Incentives of Fine Arts & Secondary school curriculum & $\mathrm{n}$ & $\bar{R}$ & $\chi^{2}$ & $P$ \\
\hline \multirow{3}{*}{ ELABORATION } & $\begin{array}{l}\text { Creative arts secondary school } \\
\text { program }\end{array}$ & 30 & 44.92 & \multirow{3}{*}{3.950} & \multirow{3}{*}{0.139} \\
\hline & General Secondary School & 27 & 43.41 & & \\
\hline & Classical Secondary School & 24 & 33.40 & & \\
\hline \multirow{3}{*}{ REDEFINITION } & $\begin{array}{l}\text { Creative arts secondary school } \\
\text { program }\end{array}$ & 30 & 54.42 & \multirow{3}{*}{15.968} & \multirow{3}{*}{0.000} \\
\hline & General Secondary School & 27 & 31.81 & & \\
\hline & Classical Secondary School & 24 & 34.56 & & \\
\hline \multirow{3}{*}{ FLEXIBILITY } & $\begin{array}{l}\text { Creative arts secondary school } \\
\text { program }\end{array}$ & 30 & 46.67 & \multirow{3}{*}{4.421} & \multirow{3}{*}{0.110} \\
\hline & General Secondary School & 27 & 35.33 & & \\
\hline & Classical Secondary School & 24 & 40.29 & & \\
\hline \multirow{3}{*}{ ORIGINALITY } & $\begin{array}{l}\text { Creative arts secondary school } \\
\text { program }\end{array}$ & 30 & 36.76 & \multirow{3}{*}{5.150} & \multirow{3}{*}{0.076} \\
\hline & General Secondary School & 27 & 48.60 & & \\
\hline & Classical Secondary School & 24 & 36.27 & & \\
\hline \multirow{3}{*}{$\begin{array}{l}\text { SENSITIVITY TO ART } \\
\text { PROBLEMS }\end{array}$} & $\begin{array}{l}\text { Creative arts secondary school } \\
\text { program }\end{array}$ & 30 & 49.65 & \multirow{3}{*}{12.175} & \multirow{3}{*}{0.002} \\
\hline & General Secondary School & 27 & 42.39 & & \\
\hline & Classical Secondary School & 24 & 28.63 & & \\
\hline \multirow{3}{*}{ FLUENCY } & $\begin{array}{l}\text { Creative arts secondary school } \\
\text { program }\end{array}$ & 30 & 44.68 & \multirow{3}{*}{1.277} & \multirow{3}{*}{0.528} \\
\hline & General Secondary School & 27 & 38.28 & & \\
\hline & Classical Secondary School & 24 & 39.46 & & \\
\hline
\end{tabular}

We further note that the outcome of the Kruskal-Wallis test indicates the existence of statistically significant differences in the redefinition factor $\left(\chi^{2}=15.968, P=0.000\right)$, which is in favour of the pupils of the creative arts secondary school program. The pupils of the other two programs achieved fairly similar results but were somewhat more successful pupils of the classical secondary school program. On the basis of the obtained result, we conclude that the pupils of the creative arts secondary school program achieved a better result in measuring artistic redefinition than other pupils. With this we answered the research question RQ2, where we were interested in which pupils would achieve better results in the factor of artistic redefinition.

The results show (Table 10) that there is no statistically significant difference between the pupils of different secondary school programs in the factor of visual flexibility. This means that pupils were similarly successful in this factor. A slightly higher result was achieved by pupils of creative arts school, followed by pupils of the classical secondary school program. With the result obtained, we answered the research question RQ3, where we were interested in which pupils would achieve better results in the factor of artistic elaboration. 
For the artistic originality, the result indicates a tendency for pupils of the general secondary school program to have an advantage over the artistic originality factor $\left(\chi^{2}=5.150, \mathrm{P}=0.076\right)$. This result can be interpreted as making the pupils of this program more relaxed and less guided at work, since there is less study work in the creative arts secondary school program, where the producing of artworks is according to specific rules, which can be reflected in lower achievement in the field of original art solutions. It is interesting that in terms of artistic originality, pupils of the artistic and classical secondary school program achieved a very similar result. With this result, we answered the research question RQ4, where we were interested in which pupils would achieve better results in artistic originality.

Looking at pupils' achievement in the factor of sensitivity to artistic problems, we find a statistically significant difference $\left(\chi^{2}=12.175, \mathrm{P}=0.002\right)$, which is in favour of the better achievement of the pupils of the creative arts secondary school program. The general secondary school pupils also achieved a fairly high score, while the performance of the classical secondary school pupils was much lower. With the result obtained, we answer the research question RQ5, where we were interested in which pupils will achieve better results in the factor of sensitivity to visual problems.

For the latter factor, i.e. for visual fluency, we did not detect statistically significant differences with regard to the type of secondary school program. However, the results of the pupils of the general secondary school program and of the classical secondary school program are very consistent, while the results of the pupils of the creative arts secondary school program were quite higher. With this result we are answering the last research question RQ6, where we were interested in which pupils will achieve better results in measuring visual fluency.

\section{Conclusion}

In our research, we have undertaken a rather neglected field in Slovenia, that is, research in the field of monitoring artistic creativity in pupils. We addressed specific educational programs. The creative arts secondary school program is special because enrolment requires tests of artistic ability and these pupils have significantly more content covering the field of fine arts. For the other two secondary school programs, classical and general, pupils are "restricted" to fine arts content and practicing only to perform content in the 1st year. For these reasons, we are particularly interested in the differences between the pupils in terms of their creative abilities. We can say that the results can also be an indicator of quality and comprehensive learning. This, to a large extent, depends on the teacher's choice of teaching methods, teaching forms, didactic communication, etc. influencing pupils' activity, motivation and learning (Shepherd, 2005). An appropriate didactic approach also showed better results in Kač Nemanič's research (2019). In accordance with the specifics of the teacher's work, the choice of teaching methods as well as the curriculum, in our research we confirmed all three set research hypotheses, with which we assumed better results in favour of the pupils 
of the creative arts secondary school program for all analysed factors. Taking into account the specificity of individual factors of artistic creativity, as well as secondary school programs whose pupils were monitored in the study, we formulated six research questions on this basis. A closer look at the results shows interesting results, which in the factor of artistic originality was achieved by the pupils of the general secondary school program. Zupančič (2015) may also confirm this, saying that curricula in secondary schools should not only include competencies in formal language skills and practical work of pupils, but also link school work with current developments in the visual arts. The results of our research can undoubtedly confirm the importance of an appropriate visual pedagogical approach and agree with Freedman when he says, "But, why is it important to have strong art education? Creative social, political and economic growth cannot be sustained or valued without the solid foundation of a professional art education for producers as well as art education for citizens who will be influenced by the creative arts and the cultural experiences they enable" (Freedman, 2008, p. 199)."

\section{References}

Dinkelmann, K. (2008). Kreativitätsförderung im Kunstunterrich. Herbert Utz Verlag GmbH. Duh, M. (1997). Likovna ustvarjalnost $\mathrm{z}$ računalniškimi ozadji v slovenski osnovni šoli. Sodobna pedagogika, 48(9-10), 509-526.

Duh, M. (1997). Razvijanje ustvarjalne osebnosti v prenovljeni slovenski osnovni šoli. [= Developing creative personality in renewed Slovenian basic school] In: Programska prenova naše osnovne in srednje šole. [= Renewal of programmes of our basic and secondary school] Portorož, ZDPDS [Zveza društev pedagoških delavcev Slovenije - Slovenian Association of Pedagogical Workers].

Duh, M. (2004). Vrednotenje kot didaktični problem pri likovni vzgoji. Maribor: Pedagoška fakulteta.

Duh, M., Čagran, B., \& Huzjak, M. (2012). Quality and quantity of teaching art appreciation. Croatian Journal of Education, 14(3), 625-655.

Duh, M., Zupančič, T., \& Čagran B. (2014). Development of art appreciation in 11-14-yearold students. The International Journal of Art \& Design Education, 33(2), 208-222. https:// doi.org/10.1111/j.1476-8070.2014.01768.x

Duh, M., \& Kač Nemanič, M. (2018). Spremljanje razvoja likovne ustvarjalnosti pri pouku grafičnega oblikovanja. Pedagoška obzorja : časopis za didaktiko in metodiko, 33(1),31-45.

Freedman, K. (2008). Leading Creativity: Responding to Policy in Art Education. In Eça, T., Mason, R. (Eds.) International Dialogues about Visual Culture, Education in Art (pp 6475). Intellect Books.

Glogovec, Z., \& Žagar, D. (1992). Ustvarjalnost: projektno vzgojno delo. Zavod Republike Slovenije za šolstvo in šport. 
Guilford, J. P. (1967). The Nature of Human Intelligence. McGraw-Hill.

Guilfrod, J. P. (1969). Intelligence, creativity and their educational implications. R. R. Knapp.

Herzog, J. (2008). Porazdelitev likovnoustvarjalnih sposobnosti med osnovnošolci. Revija za elementarno izobraževanje, 1(3-4), 87-94.

Herzog, J. (2009). Dejavniki likovne ustvarjalnosti in likovnopedagoško delo. Revija za elementarno izobraževanje, 2(2-3), 19-31.

Herzog, J. (2015). Sodobno umetniško delo kot izhodišče za didaktično načrtovanje pouka likovne umetnosti z vidika ekologije. In Duh, M. (Ed.). Okoljska vzgoja in trajnostni razvoj v interakciji z okoljskimi spremembami (pp. 72-85), Maribor: Pedagoška fakulteta; Rakičan: RIS Dvorec.

Herzog, J. (2017). Methods of implementing contemporary Slovenian art practices in basic school art syllabus - emphasis on ecology. In: Vujičić, L. (Ed.). Contributions to the development of the contemporary paradigm of the institutional childhood: an educational perspective (pp. 103-115), (Erziehungswissenschaft, bd. 83). Lit. Wien; Zürich: Lit. Verlag.

Herzog, J., Duh, M., \& Krašovec, B. (2017). Modern art in the function of developing ecological awareness. In: Celec, R. (Ed.). Development of ecological responsibility (pp. 93106), Hamburg: Verlag Dr. Kovač

Jurman, B. (2004). Inteligentnost-ustvarjalnost-nadarjenost. Center za psihodiagnostična sredstva.

Kač Nemanič, M. (2019). Pupil's Attitudes Towards Didactic Characteristics in Graphic Design Classes. Journal of Elementary Education, 12(2), 199-214. https://doi.org/10.18690/ rei.12.2.199-214.2019

Kraguljac, M., \& Karlavaris, B. (1970). Estetsko procenjivanje u osnovnoj školi. Umetnička akademija.

Karlavaris, B. (1974). Monitoring the artistic development of the same students and the development trend of intellectual-artistic maturity and creative and emotional maturity of children from 3-16 years. Center for Art Education of Children and Youth in Vojvodina.

Karlavaris, B., \& Kraguljac. M (1981). Razvijanje kreativnosti putem likovnog vaspitanja osnovnoj školi. Institut za pedagoška istraživanja, Prosveta.

Kaufman, J. C., \& Baer, J. (2004). Sure, I'm creative - but not in mathematics: Self-reported creativity in diverse domains. Empirical Studies of the Arts, 22(2), 143-155. https://doi. org/10.2190/26HQ-VHE8-GTLN-BJJM

Kemple, K., \& Nissenberg, S. (2000). Nurturing creativity in early childhood education: families are part of it. Early Childhood Education Journal, 28(1), 67-71.

Kljajič, A. (2016). Vpliv predšolskega varstva in šole na likovno izražanje učencev v prvih razredih osnovne šole. ( Doctoral dissertation). Pedagoška fakulteta Univerze v Mariboru.

Kozhevnikov, M., Kozhevnikov, M., Jiao Yu, Ch., \& Blazhenkova O. (2013). Creativity visualization abilities and visual cognitive style. British Journal of Education Psychology, 83(2), 196-209. https://doi.org/10.1111/bjep.12013

Mumford, M. D. (2003). Where have we been, where are we going: Taking stock in creativity research. Creativity Research Journal, 15(2-3), 107-120. https://doi.org/10.1080/1040041 $\underline{9.2003 .9651403}$

Oral, G., Kaufman, J. C., \& Agars, M. D. (2007). Examining creativity in Turkey: Do Western findings apply? High Ability Studies, 18(2), 235-246. https://doi.org/10.1080/13598130701709590 
Pečjak, V. (1987). Misliti, delati, živeti ustvarjalno. Državna založba Slovenije.

Pečjak, V. (2005). Novi pogledi na ustvarjalnost. In Vizjak Pavščič, M., Salobir, M.\& Jeraj, M (Eds). Inteligentnost, ustvarjalnost, nadarjenos. Zbornik razprav 5. Dnevi slovenskih psihologov (pp. 141-154). Društvo psihologov Slovenije.

Pérez-Fabello, M., \& Campos, A. (2011). Dissociative Experiences and Creativity in Fine Arts Pupils. Creativity Research Journal, 23(1), 38-41. https://doi.org/10.1080/10400419 .2011 .545721

Plucker J. A., Beghetto, R. A., \& Dow, G. T. (2004). Why isn't creativity more important to educational psychologists? Potential, pitfalls, and future directions in creativity research. Educational Psychologists, 39(2), 83-96. https://doi.org/10.1207/s15326985ep3902 1

Runco, M. A. (2007). Creativity theories and themes: Research development and practice. Elsevier Academic Press.

Shepherd, G. J. (1993). Building a discipline of communication. Journal of Communication, 43(3), 83-91. https://doi.org/10.1111/j.1460-2466.1993.tb01279.x

Trstenjak, A. (1981). Psihologija ustvarjalnosti. Slovenska matica.

Vrlič, T. (2001). Likovno-ustvarjalni razvoj otrok v predšolskem obdobju. Debora.

Ward, T. B., Smith, S. M., \& Finke, R. A. (1999). Creative cognition. In R. Sternberg (Ed.), Handbook of Creativity (pp. 189-212). Cambridge University Press. https://doi.org/10.1017/ CBO9780511807916.012

Zupančič, T. (2015). Slovenski učni načrt za predmet likovna umetnost v gimnazijskem programu v primerjavi s podobnimi dokumenti evropskih držav. Revija za elementarno izobraževanje, 8 (4), 65-85.

Žagar, D. (1992). Razvijanje ustvarjalnosti učencev. Slovensko društvo pedagogov.

\section{Jerneja Herzog}

Department of Fine Arts

Faculty of Education

University of Maribor

Koroška cesta 160, 2000 Maribor, Slovenia

jerneja.herzog@um.si 


\section{Analiza kreativnih sposobnosti u različitim srednjoškolskim programima u Sloveniji}

\section{Sažetak}

Na području praćenja umjetničke kreativnosti u srednjim školama u Sloveniji nedostaje istraživanja. Istraživanje je provedeno na populaciji srednjoškolca $(N=81)$ različitih srednjoškolskih programa u Sloveniji u dobi od 16 godina, a pratili smo njihove umjetničko kreativne sposobnosti. Analizirali smo postignuća srednjoškolca u smislu zajedničkih umjetničkih sposobnosti, a također smo analizirali razlike među skupinama čimbenika umjetničkog stvaralaštva koji potiču i omogućavaju umjetničko stvaralaštvo, kao i u pogledu razlika u pojedinim čimbenicima umjetničkog stvaralaštva. Cilj analize bio je utvrditi razlike među različitim srednjoškolskim programima.

Rezultati pokazuju da srednjoškolci u umjetničkom srednjoškolskom programu uglavnom prednjače spram učenika općeg srednjoškolskog programa. Međutim, učenici općega srednjoškolskog programa postigli su bolje rezultate u pogledu umjetničke originalnosti. Takav rezultat potvrđuje da se na polju razvoja umjetničkog stvaralaštva mogu postići dobri rezultati i u općim srednjoškolskim programima s odgovarajućim likovno pedagoškim radom.

Ključne riječi: čimbenici umjetničke kreativnosti; učenici; kreativnost; umjetnička kreativnost 